\title{
IN MEMORIAM: ROSALIND TAYLOR
}

\author{
by Dorothy Rhodes, Moose Jaw, Saskatchewan
}

On its tenth anniversary, March 20, 1967, the Moose Jaw Natural History Society paid homage to its foundress, Mrs. F. B. (Rosalind) Taylor. One year later, at its annual meeting, the Society held a short memorial service for Mrs. Taylor whose untimely death occurred on February 29, 1968.

Mrs. Taylor, born Constance Rosalind Russell on February 5, 1900, in Minerva, Ohio, attended Mount Union Methodist College in Alliance, Ohio, then taught high school in her home state, specializing in Latin and English. On October 7, 1933, she married Frank Butler Taylor of Liverpool, England, who was at that time an engineer with Imperial Oil at Newport News, Virginia. His work brought them to Montreal, Vancouver, London (Ontario), and Ottawa. For the last eleven years of her life, Mrs. Taylor resided with her husband in Moose Jaw. Predeceased by her husband just four months before her own death, Rosalind Taylor is survived by one daughter, Mrs. Robert E. Jenkins of Cuyahoga Falls, Ohio, and four grandchildren.

While living in Ottawa Mrs. Taylor joined the Ottawa Natural History Society and became an ardent birdwatcher. When she and her husband came to Moose Jaw in 1957, one of her first activities was the founding of the Moose Jaw Natural History Society.

She was enthusiastic about all phases of natural history and inspired a love of nature in those around her, especially so in the young people whom she encouraged in the practice of conservation. One of her great ambitions was to gather and permanently record observations made in the Moose Jaw area by early ornithologists and in recent years by members of the Moose Jaw Natural History Society. This culminated in the publication by Leith Knight of Birds of the Moose Jaw Area on October 1.5, 1967. Mrs. Taylor also spent several years gathering records of the occurrence of the Red-

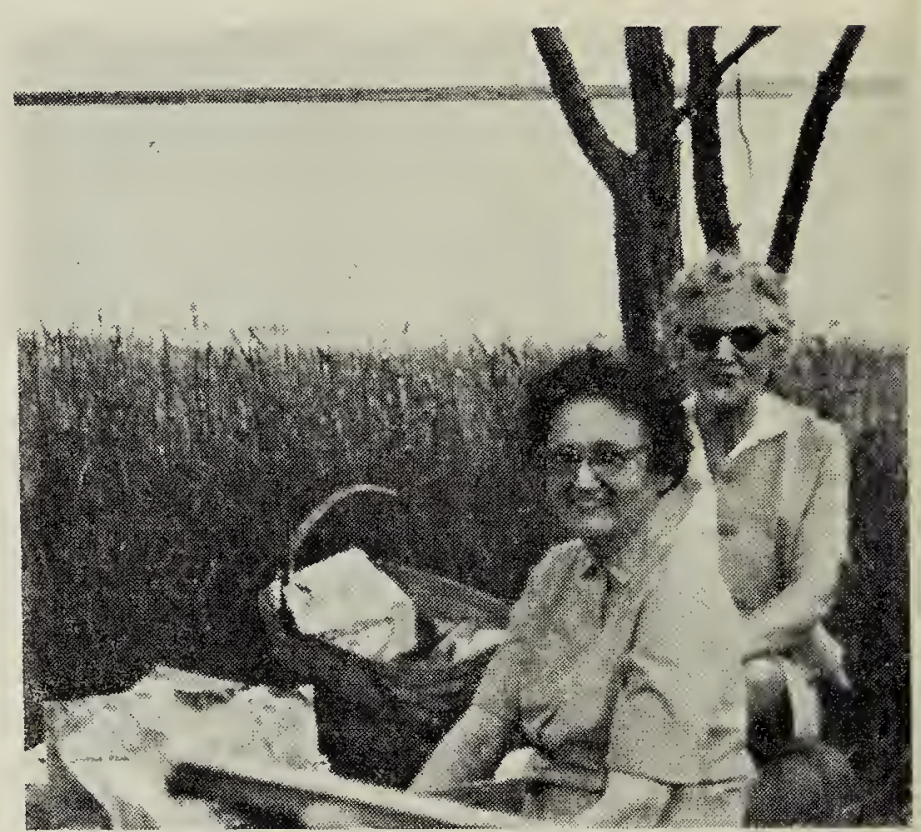

Rosalind Taylor, June 1967

headed Woodpecker in Saskatchewan, and her completed study was published in the Blue Jay (24:56-64, June, 1966).

Although she never became a naturalized Canadian, she strove to protect our heritage of wildlife and beauty and prevent us from making the same mistakes that have led to the destruction of many areas of natural beauty in her own country.

Rosalind Taylor had an abiding interest in all intellectual pursuits. She was a valued member of the Wilson MacDonald Poetry Society to which she contributed many fascinating papers. She was a prime mover in the Overture Concert Association, and was active in the University Women's Club as well as a local art group. As a member of the executive of the Saskatchewan Natural History Society, she was a worthy liaison between the provincial and local societies.

Recently, when choosing a quotation for a printed program of the Moose Jaw Natural History Society, Rosalind Taylor turned to one her beloved New England poets, Ralph Waldo Emmerson -

"Nature and books belong to the eyes that see them."

And because she opened so many eyes to the beauty of nature, she will be remembered. 